\title{
Plasmodium falciparum glutamate dehydrogenase $a$ is dispensable and not a drug target during erythrocytic development
}

\author{
Janet Storm ${ }^{1}$, Jan Perner ${ }^{1}$, Isabela Aparicio ${ }^{2}$, Eva-Maria Patzewitz ${ }^{1,4}$, Kellen Olszewski ${ }^{3}$, Manuel Llinas ${ }^{3}$,
} Paul C Engel ${ }^{2}$ and Sylke Müller ${ }^{*}$

\begin{abstract}
Background: Plasmodium falciparum contains three genes encoding potential glutamate dehydrogenases. The protein encoded by gdha has previously been biochemically and structurally characterized. It was suggested that it is important for the supply of reducing equivalents during intra-erythrocytic development of Plasmodium and, therefore, a suitable drug target.

Methods: The gene encoding the NADP(H)-dependent GDHa has been disrupted by reverse genetics in $P$. falciparum and the effect on the antioxidant and metabolic capacities of the resulting mutant parasites was investigated.

Results: No growth defect under low and elevated oxygen tension, no up- or down-regulation of a number of antioxidant and NADP(H)-generating proteins or mRNAs and no increased levels of GSH were detected in the D10 $0^{\Delta g \text { dha }}$ parasite lines. Further, the fate of the carbon skeleton of $\left[{ }^{13} \mathrm{C}\right]$ labelled glutamine was assessed by metabolomic studies, revealing no differences in the labelling of $\alpha$-ketoglutarate and other TCA pathway intermediates between wild type and mutant parasites.
\end{abstract}

Conclusions: First, the data support the conclusion that D10 $0^{\Delta g d h a}$ parasites are not experiencing enhanced oxidative stress and that GDHa function may not be the provision of $\operatorname{NADP}(H)$ for reductive reactions. Second, the results imply that the cytosolic, $\mathrm{NADP}(\mathrm{H})$-dependent $\mathrm{GDH}$ a protein is not involved in the oxidative deamination of glutamate but that the protein may play a role in ammonia assimilation as has been described for other NADP(H)dependent GDH from plants and fungi. The lack of an obvious phenotype in the absence of GDHa may point to a regulatory role of the protein providing glutamate (as nitrogen storage molecule) in situations where the parasites experience a limiting supply of carbon sources and, therefore, under in vitro conditions the enzyme is unlikely to be of significant importance. The data imply that the protein is not a suitable target for future drug development against intra-erythrocytic parasite development.

\section{Background}

Glutamate dehydrogenases (GDH) are enzymes that catalyse the reversible oxidative deamination of L-glutamate to form $\alpha$-ketoglutarate and ammonia using $\mathrm{NADP}(\mathrm{H})$ or $\mathrm{NAD}(\mathrm{H})$ as co-factors:

\footnotetext{
* Correspondence: sylke.muller@glasgow.ac.uk

'Institute of Infection, Immunity \& Inflammation, Wellcome Trust Centre for Molecular Parasitology, College of Medical, Veterinary and Life Sciences, Sir Graeme Davies Building, University of Glasgow, 120 University Place, Glasgow G12 8TA, UK

Full list of author information is available at the end of the article
}

$\alpha-$ ketoglutarate $+\mathrm{NH}_{3}+\mathrm{NAD}(\mathrm{P}) \mathrm{H} \rightleftarrows \mathrm{L}-$ glutamate $+\mathrm{NAD}(\mathrm{P})^{+}$

The enzymes are at the branch point of nitrogen and carbon metabolism and either assimilate ammonia and provide glutamate as nitrogen storage molecule or dissimilate ammonia and provide $\alpha$-ketoglutarate that can feed into tricarboxylic acid (TCA) metabolism. There are three different types of GDH depending on their cofactor specificity. The enzymes specific for $\mathrm{NAD}(\mathrm{H})$ generally catalyse the oxidative deamination of L-glutamate (to generate $\alpha$-ketoglutarate) with an alkaline $\mathrm{pH}$ optimum; the enzymes specific for $\mathrm{NADP}(\mathrm{H})$ usually carry 
out the reductive amination of $\alpha$-ketoglutarate (to generate L-glutamate) with a neutral $\mathrm{pH}$ optimum. The third type, represented by the vertebrate GDH enzymes, can use both co-factors for the deamination of L-glutamate [1].

The human malaria parasite Plasmodium falciparum contains three genes encoding potential GDH proteins; two are found on chromosome 14 (PF14_0164 and PF14_0286, encoding GDHa and b, respectively) and one is present on chromosome 8 (PF08_0132 encoding GDHc) [2,3]. GDHa and GDHb are NADP(H)-dependent and the primary sequence of $\mathrm{GDHb}$ suggests the protein is located in the apicoplast, while the localisation and co-factor specificity is not predictable for GDHc. This presence of multiple GDH proteins is reminiscent of plants and fungi [4-7]. In plants, the two NAD $(\mathrm{H})$ dependent GDHs are essential for carbon metabolism while the role of the putative $\mathrm{NADP}(\mathrm{H})$-dependent GDH is thought to provide glutamate through $\mathrm{NH}_{4}{ }^{+}$ assimilation [7-10]. In fungi, the $\operatorname{NADP}(\mathrm{H})$ dependent GDH are also involved in $\mathrm{NH}_{4}{ }^{+}$assimilation $[4,5,11]$.

Plasmodium falciparum gdha was previously cloned and recombinant protein was biochemically and structurally characterized [3,12-14]. The kinetic parameters are comparable to other GDH enzymes using $\mathrm{NADP}(\mathrm{H})$ as co-factor and suggest that the enzyme catalyses both the oxidative deamination of glutamate and the reductive amination of $\alpha$-ketoglutarate [13]. It was hypothesized that one of the major roles of GDHa is to provide reducing equivalents in form of NADPH that is required for downstream redox reactions, carried out by the disulphide oxidoreductases glutathione reductase and thioredoxin reductase [14-17]. Thus, the enzyme was considered integral to the parasite's antioxidant machinery and thought to be a potential drug target $[3,13,14,18,19]$. Recently, it was shown that P. falciparum growth was susceptible to inhibition by the GDH inhibitor, isophthalic acid. However, this effect was only achieved at high $\mu \mathrm{M}$ concentrations suggesting that the inhibitory effect may also be attributable to inhibition of one or both of the other two GDH proteins [3]. A recent high-throughput drug screen against several potential drug targets for the development of Plasmodium, which included GDHa, did not identify any specific compounds that were inhibitory for the enzyme, questioning the suitability of GDHa as a drug target because it may simply not be "druggable" [20].

To genetically validate GDHa as a potential target for the design of new anti-malarials during their intra-erythrocytic development this study generated gdha null mutants of $P$. falciparum and investigated their phenotypes with respect to their abilities to withstand oxidative challenges, their expression levels of antioxidant proteins and the metabolic fate of isotope labelled glutamine.

\section{Methods}

\section{Materials}

WR99210 was a kind gift from Jacobus Pharmaceuticals (USA). Plasmids pHH1 and pHH2 were kind gifts from Professor A. F. Cowman (The Walter and Eliza Hall Institute, Melbourne, Australia) [21,22]. Human blood was obtained from the Glasgow blood transfusion services. Specific antibodies, used in western blot experiments, were generated in rabbit or rat using recombinantly expressed protein [23-28] (Eurogentec, Belgium). Secondary antibodies were obtained from Promega. Anti-GST antibodies were a kind gift from Professor E. Liebau (University of Münster, Germany), antiSOD 1 and 2 were obtained from Dr J. Khalife (University of Lille Nord de France, Institut Pasteur de Lille, France) and GDHa antibodies were a gift from Professor L. Krauth-Siegel (University of Heidelberg, Germany). [8- $\left.{ }^{3} \mathrm{H}\right]$-hypoxanthine (specific activity: $10-30 \mathrm{Ci} / \mathrm{mmol}$ ) was from American Radiolabeled Chemicals. U- $\left[{ }^{13} \mathrm{C}\right]$ glutamine and $\mathrm{U}-\left[{ }^{13} \mathrm{C}-{ }^{15} \mathrm{~N}\right]$ glutamine were purchased from CK gas, UK. All other chemicals were purchased from Sigma UK unless otherwise stated.

\section{Knockout and expression constructs of $P$. falciparum gdha} The knockout and expression fragments of the $P$. falciparum gdha gene were amplified from P. falciparum 3D7 or D10 genomic DNA using Pfx Supermix (Invitrogen, UK). The specific oligonucleotide primers 5'GCGCAGATCTGGTTTACGATTTCATCC-3' (sense) and 5'-CGCGCTCGAG(TTA)TTGCTGCTTTTGA TGG-3' (antisense) with the BglII and XhoI restriction sites, respectively, in bold, and an artificial stop codon (in brackets) within the antisense oligonucleotide, were used to generate the $841 \mathrm{bp}$ insert equivalent to nucleotides 339-1179 of the gdha open reading frame for the gdha knockout construct. For the gdha-GFP construct the primers 5'-GCGCAGATCT(ATG)AGTGCTCTTAAAG-3' (sense) and 5'-CGCGCCTAGGAAAACAACCTTG-3' (anti sense) with the BglII and AvrII restriction sites, respectively, in bold, and an artificial start codon (in brackets) within the sense oligonucleotide were used to generate a full-length protein with a C-terminal GFP-tag. The PCR products were subcloned into the TOPO-Blunt PCR cloning vector (Invitrogen) and its sequences were verified (Eurofins MWG Operon) before they were cloned into the $P$. falciparum transfection plasmid $\mathrm{pHH} 1$ or $\mathrm{pHH} 2$, respectively, to generate $\mathrm{pHH} 1-\Delta g d h a$ and $\mathrm{pHH} 2-g d h a-G F P$.

\section{Parasite culture, transfection, determination of $\mathrm{IC}_{50}$ values, and parasite growth rate}

The P. falciparum D10 strain (Papua New Guinea) was cultured according to Trager and Jensen [29] in RPMI 1640 (Invitrogen, UK) containing $11 \mathrm{mM}$ glucose, $0.5 \%$ 
Albumax II (w/v) (Invitrogen, UK), $200 \mu \mathrm{M}$ hypoxanthine, $20 \mu \mathrm{g} / \mathrm{ml}$ gentamycin (PAA) in human erythrocytes between $0.5 \%$ and $5 \%$ haematocrit. Parasite cultures were maintained under an atmosphere of reduced oxygen $\left(1 \% \mathrm{O}_{2}, 3 \% \mathrm{CO}_{2}\right.$ and $\left.96 \% \mathrm{~N}_{2}\right)$ and for the growth experiment also at atmospheric oxygen with $5 \% \mathrm{CO}_{2}$ at $37^{\circ} \mathrm{C}$. Parasites were synchronized using sorbitol according to Lambros and Vanderberg [30] and freed from erythrocytes using saponin according to Umlas and Fallon [31]. Parasitaemia was determined using Giemsa stained thin smears and the number of live, isolated parasites was determined using a Neubauer haemocytometer.

Transfection of pHH1- $\Delta g d h a$ and $\mathrm{pHH} 2-$ gdha-GFP into $P$. falciparum erythrocytic stages was performed as described previously Crabb et al [32]. WR99210 resistant parasites appeared between 25 and 60 days after transfection. Parasites were cloned by limiting dilution according to Kirkman et al [33].

The effects of $N$-methylphenazonium methosulfate, tert-butylhydroperoxide and L-cycloserine on the viability of $P$. falciparum erythrocytic stages were determined by measuring the incorporation of $\left[{ }^{3} \mathrm{H}\right]$-hypoxanthine in the presence of increasing drug concentrations according to Desjardins et al [34].

The growth rates of D10 and gdha null mutants $\left(\mathrm{D} 10^{\Delta \text { gdha }}\right)$ were determined as described by Günther et al [35]. Parasites were synchronized twice and after $24 \mathrm{~h}$ diluted to $0.5 \%$ parasitaemia at $5 \%$ haematocrit. Giemsa stained thin smears were prepared daily and parasitaemia determined by counting 1000 erythrocytes per smear. The cultures were maintained at a suitable parasitaemia throughout the 6 day experiment by diluting them 1:5 every second day.

\section{Fluorescent microscopy}

D10 transfected with pHH2-gdha-GFP, and resistant to WR99210, at $10 \%$ parasitaemia were incubated for 5 min at $37^{\circ} \mathrm{C}$ with $25 \mathrm{nM}$ MitoTracker Red and $100 \mu \mathrm{g} /$ ml Hoechst 33342 (both Invitrogen, UK), washed and resuspended in warm complete medium. Cells were viewed with the Applied Precision Deltavision Deconvolution microscope system (Olympus IX-70 invert microscope) fitted with a Coolsnap HQ camera and images were processed with the SoftWoRx software.

\section{Preparation of genomic DNA, RNA and protein from $P$. falciparum}

Parasites were released from erythrocytes by saponin lysis and genomic DNA was isolated using the QIAamp DNA Mini Kit (Qiagen, UK). RNA was extracted from tightly synchronized trophozoites using TRIZOL (Sigma) according to the manufacturer's instructions with modifications as described by Smith et al [36]. The final RNA pellet was resuspended in 20-50 $\mu$ l nuclease free water and stored at $-80^{\circ} \mathrm{C}$. Protein extracts for western blots were prepared by resuspending the parasite pellets in lysis buffer (PBS, 0.5\% (v/v) TritonX-100, 1 $\mathrm{mM}$ phenylmethylsulphonyl fluoride, $1 \mathrm{mM}$ benzamidine, $20 \mu \mathrm{M}$ leupeptin, $10 \mu \mathrm{M}$ E-64, $2 \mu \mathrm{M}$ 1,10-phenanthroline, $4 \mu \mathrm{M}$ pepstatin A) followed by three cycles of freeze/thawing, a $15 \mathrm{~min}$ incubation on ice and $5 \mathrm{~min}$ centrifugation at $17,000 \mathrm{~g}$. For enzyme assays the parasites were lysed as above in $100 \mathrm{mM}$ potassium phosphate buffer $\mathrm{pH} 7.0$ in the presence of protease inhibitors and centrifuged for $30 \mathrm{~min}$ at 17,000 g. Concentration of soluble protein was determined using the Bradford assay with bovine serum albumin as a standard [37].

\section{Southern blotting}

One to three $\mu \mathrm{g}$ of genomic DNA isolated from D10 and D10 transfected with $\mathrm{pHH} 1-\Delta g d h a$ were subjected to digestion with NdeI overnight before the DNA was separated on a $0.8 \%$ agarose gel and subsequently blotted onto positively charged nylon membrane. After cross-linking the DNA to the membrane, the blot was prehybridized at $55^{\circ} \mathrm{C}$ before the probe (coding region of the gdha gene) was added for an overnight incubation. The probe was prepared using the AlkPhos Direct Labeling and Detection System (VWR, UK) and successive washes were performed according to the manufacturer's instructions. The blot was exposed to autoradiography film (Kodak) for 1 to 16 hours.

\section{Western blotting}

Ten $\mu$ g of protein from D10, D10 $0^{\Delta g d h a}-1$ and D10 $0^{\Delta g d h a}-2$ were separated on $10 \%$ or $15 \%$ SDS-PAGE gels and blotted onto nitrocellulose using a Transblot Semidry transfer system (BioRad). The membranes were blocked in 3\% BSA in PBS (w/v) containing 0.5\% Tween $20(\mathrm{v} / \mathrm{v})$ at $4^{\circ} \mathrm{C}$ overnight before they were probed with the primary antibodies raised against $P$. falciparum GDHa $(1: 2,000), P$. falciparum glutathione $S$-transferase $(1: 5,000), \quad P$. falciparum glutathione reductase (1:100,000), P. falciparum superoxide dismutase 1 and 2 $(1: 5,000)$, P. falciparum 2Cys-peroxiredoxin 1 (1: 100,000), P. falciparum 1Cys-peroxiredoxin $(1: 100,000)$, $P$. falciparum thioredoxin $1(1: 10,000)$ and $P$. falciparum isocitrate dehydrogenase $(1: 30,000)$. Depending on the respective size of the protein under investigation, an antibody raised against $P$. falciparum branched chain acyltransferase (BCDH-E2 at 1:5,000), detecting a protein of $50 \mathrm{kDa}$, or the P. falciparum 1Cys- peroxiredoxin $(25 \mathrm{kDa})$ antibody was used as loading control after it was established that their expression was unchanged in the parent and mutant parasites. The secondary antirabbit or anti-rat (for SOD1 and 2 detection) HRP- 
conjugate antibodies were used at 1:10,000 dilution and the signals were visualized using the Immobilon Western kit (Millipore). Expression relative to the loading control was analysed using LabImage 1D software (Kapelan Bio-Imaging Solutions, Germany). The average expression of the proteins was determined from 2 to 3 independent protein extracts.

\section{Quantitative real-time PCR}

RNA was isolated as described above and treated with TURBO-DNA free (Ambion, UK) before synthesis of cDNA with the RETROscript kit (Ambion, UK) following manufacturer's instructions. Real time PCR reactions were performed in $25 \mu \mathrm{l}$ using QuantiTect SYBR Green master mix (Qiagen, UK) and primers at a final concentration of $0.3 \mu \mathrm{M}$ with the 7500 Real Time PCR system (Applied Biosystems, UK). The transcription levels of gdhb, gdhc, $\gamma$-glutamylcysteine synthetase ( $\gamma g c s)$, glutathione synthetase (gs) and glucose-6 phosphate dehydrogenase ( $g-6 p d h)$, were examined using the primer pairs 5'-GCGTATGCAAAGAGAAGAGGAA-3' and

5'-GTAGAAGTATAGCCGTAGTTGTGTA-3' (gdhb),

5'-TCATCGTCTCCATCATCAGTTC-3' and

5'-CTCACATTACTCTGAGCACATCT $(g d h c)$,

5'-TCCTTGCTCTTACTGCATGTACT-3' and

5'-TTCCGTTCTACAATCAACACTGT-3' ( $/ g c s)$,

5'-CTTTAGAGCATTATATACACCTAACCA-3' and

5'-CGAACCAACAAGTTGATAAGGTA-3' ( $g s)$,

5'-GACCTGAATGATTTTAATTGGAAAGCA-3' and

5'-CATCTATCGGAGTTCGACCTC-3' (g-6pdh).

Seryl-t-RNA synthase was used as endogenous control, as it had been previously described to have a uniform transcription pattern throughout the parasite life cycle $[38,39]$. The primer pair

5'-AAGTAGCAGGTCATCGTGGTT-3' and 5'TTCGGCACATTCTTCCATAA-3' was used and the efficiency of its amplification was similar to $g d h b$, $g d h c$, $\gamma g c s, g s$ and $g-6 p d h$. PCR cycling conditions were $50^{\circ} \mathrm{C}$ for $2 \mathrm{~min}, 95^{\circ} \mathrm{C}$ for $15 \mathrm{~min}$, followed by 40 cycles of $95^{\circ}$ $\mathrm{C}$ for $15 \mathrm{sec}, 54^{\circ} \mathrm{C}$ for $30 \mathrm{sec}$ and $68^{\circ} \mathrm{C}$ for $35 \mathrm{sec}$. Relative expression levels were calculated by the $\Delta \Delta C T$ method (User Bulletin 2, Applied Biosystems, http:// www.appliedbiosystems.com).

\section{GDH activity assays}

GDHa activity was detected using a variation of the MTT assay [40]. Five $\mu \mathrm{g}$ of purified recombinant GDHa [3] and $10 \mu \mathrm{g}$ of parasite extract was loaded onto $10 \%$ polyacrylamide gel and resolved under non-denaturing conditions. Gels were washed briefly in $100 \mathrm{mM}$ potassium phosphate buffer pH 8.0 containing $1 \mathrm{mM}$ EDTA and then incubated in the same buffer with $0.3 \mathrm{mg} / \mathrm{ml}$ 2-(4-iodophenyl)-3-(4-nitrophenyl)-5-phenyltetrazolium chloride, $0.03 \mathrm{mg} / \mathrm{ml}$ phenazine ethosulphate, with 100
$\mathrm{mM} \mathrm{L}$-glutamate and $1 \mathrm{mM} \mathrm{NADP}{ }^{+}$at $37^{\circ} \mathrm{C}$, in the dark, until the appearance of dark red coloured bands (formazan deposits). The reaction was stopped by washing gels thoroughly with distilled water.

Total GDH activity was determined in parasite lysate using a spectrophotometric assay based on the oxidation of $\mathrm{NAD}(\mathrm{P}) \mathrm{H}$ or the reduction of $\mathrm{NAD}(\mathrm{P})^{+}$, respectively [18]. The forward reaction contained 50 to $100 \mu \mathrm{g}$ of parasite lysate isolated from D10 or D10 $0^{\Delta g d h a}-1$ or D10 ${ }^{\Delta \text { gdha }}-2,10 \mathrm{mM} \alpha$-ketoglutarate, $40 \mathrm{mM} \mathrm{NH}_{4} \mathrm{Cl}, 200$ $\mu \mathrm{M}$ NADPH or NADH in $100 \mathrm{mM}$ potassium phosphate buffer $\mathrm{pH}$ 7.0. The decrease in absorbance was followed at $340 \mathrm{~nm}$ at $25^{\circ} \mathrm{C}$ (Uvikon 2501, Shimadzu). The reverse reaction contained $100 \mu \mathrm{g}$ of parasite extract, $10 \mathrm{mM}$ glutamate, $1 \mathrm{mM} \mathrm{NADP}{ }^{+}$or $\mathrm{NAD}^{+}$in $100 \mathrm{mM}$ potassium phosphate buffer $\mathrm{pH}$ 8.0. The increase of absorbance was followed at $340 \mathrm{~nm}$ at $25^{\circ} \mathrm{C}$. The specific activity was determined using the molar extinction coefficient of NAD(P)H of $6,220 \mathrm{M}^{-1} \mathrm{~cm}^{-1}$ at $340 \mathrm{~nm}$.

\section{Glutathione determination}

Glutathione (GSH) levels were determined by HPLC as described by Williams et al [41]. Parasites were isolated from $20 \mathrm{ml}$ of tightly synchronized culture $\left(\sim 2-5 \times 10^{7}\right.$ parasites) by saponin lysis, as described above, and parasites were incubated for $45 \mathrm{~min}$ at room temperature in $50 \mu \mathrm{l}$ of $40 \mathrm{mM} \mathrm{N}$-[2-hydroxyethyl]-piperazine-N'[3propanesulfonic acid], $4 \mathrm{mM}$ diethylenetriamine pentaacetic acid, $\mathrm{pH}$ 8.0, containing $0.7 \mathrm{mM}$ tris(2-carboxyethyl)phosphine. $50 \mu \mathrm{l}$ of $2 \mathrm{mM}$ monobromobimane in ethanol was added and samples heated to $70^{\circ} \mathrm{C}$ for 3 min before extracts were deproteinized for $30 \mathrm{~min}$ on ice by addition of $100 \mu \mathrm{l} 4 \mathrm{M}$ methanesulfonic acid, $\mathrm{pH}$ 1.6. Precipitated protein was removed by centrifugation for $40 \mathrm{~min}$ at $13,000 \mathrm{~g}$ at $4^{\circ} \mathrm{C}$ and the supernatant was analysed by HPLC as described by Williams et al [41].

\section{Metabolic labelling and mass spectrometry}

Parasites were synchronized twice, 4 hours apart, and after 35 hours washed in glutamine-free medium and diluted to $7 \%$ parasitaemia and $0.7 \%$ haematocrit in medium containing $2 \mathrm{mM} \mathrm{U}-\left[{ }^{13} \mathrm{C}\right]$ glutamine or $\mathrm{U}-\left[{ }^{13} \mathrm{C}\right.$ ${ }^{15} \mathrm{~N}$ ] glutamine. At this stage the parasites are early rings and after 32 hours (within 1 cycle) the metabolites from the medium and red blood cells were extracted with $80 \%$ methanol on dry ice, as described by Olszewski et al [42]. Uninfected red blood cells were incubated in standard culture medium at 5\% haematocrit at $37^{\circ} \mathrm{C}$ for 20 hours prior to the metabolic labelling, as described above, to activate their metabolism. The metabolites were analysed by LC-MS using a Synergy HydroRP column (Phenomenex, UK) and an Exactive orbitrap mass spectrometer (Thermo Fisher Scientific, UK) and 
RAW files were converted and loaded into MAVEN, as detailed by Olszewski et al [42].

\section{Data analysis}

Experiments were performed at least in duplicate using independent parasite preparations. Graphs were generated and statistical analyses performed using GraphPad Prism version 5 for Windows (GraphPad Software, San Diego California USA). Significance between the D10 ${ }^{\Delta g d h}$ clones and D10 was tested using ANOVA with Newman Keuls post test. The $\mathrm{IC}_{50}$ values were calculated by non linear regressing of the sigmoidal doseresponse equation (GraphPad Software). Densitometry of protein expression was analysed using LabImage 1D software (Kapelan Bio-Imaging Solutions, Germany).

\section{Results}

Localization of GDHa in P. falciparum

The location of GDHa was assessed by expressing the coding region of gdha, C-terminally tagged with green fluorescent protein (GFP), from an episome in P. falciparum D10 intra-erythrocytic stages. Live parasites were incubated with the nuclear stain Hoechst 33342 and the mitochondrial stain MitoTracker Red and microscopy revealed that the GFP-fusion protein was present exclusively in the cytosol of the parasites (Figure 1).

\section{Disruption of $g d h a$ in $P$. falciparum}

The D10 strain of $P$. falciparum was used to disrupt the gdha gene locus using the plasmid pHH1- $\Delta g d h a$ by single cross-over homologous recombination (Figure 2A). The Southern blot shows that upon diagnostic digest of genomic DNA, isolated from D10, D10 $0^{\Delta g d h}$ and the clones $\mathrm{D} 10^{\Delta g d h}-1$ and $\mathrm{D} 10^{\Delta g d h}-2$, the banding pattern obtained with a gdha-specific probe is consistent with a disruption of the gdha locus by the transfected plasmid pHH1- gdha (Figure 2B). The gdha band characteristic for the endogenous gene locus $(5.3 \mathrm{~kb})$ had disappeared in the cloned parasite lines, while the diagnostic bands for integration of the transfected plasmid into the gdha gene locus were present $(4.0 \mathrm{~kb}$ and $7.2 \mathrm{~kb})$. Additionally, the cloned parasite lines still maintained the

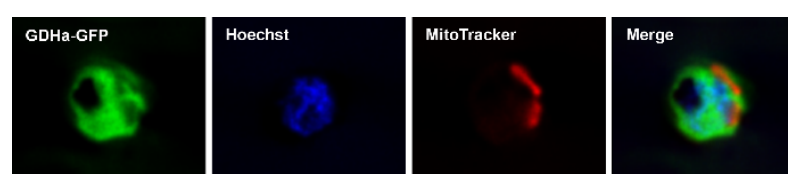

Figure 1 Cytosolic localization of GDHa D10 parasites were transfected with pHH1-gdha-GFP and WR99210-resistant parasites were analysed by fluorescence microscopy. GDHa-GFP (panel 1) does not co-localize with the nucleus (Hoechst 33342 staining, panel 2) nor with the mitochondrion (MitoTracker staining, panel 3). From the merged image it is clear that GDHa is a cytosolic protein. transfected plasmid (5.8 kb). D10 ${ }^{\Delta g d h}-1$ and D $10^{\Delta g d h}-2$ no longer expressed the GDHa protein $(49.5 \mathrm{kDa})$ as shown by western blotting using a GDHa-specific polyclonal antiserum. A non-specific $32 \mathrm{kDa}$ protein is also detected, which serves as a loading control for the parasite extracts and verifies that equal amounts of protein are present in all three lanes of the blot (Figure 2C). The D $10^{\Delta g d h a}$ clones also no longer displayed GDHa enzymatic activity as assessed by an in-gel activity assay. Purified recombinant GDHa was used as a control to verify that the reaction band detected in the parasite lysate was the result of GDHa activity (Figure 2D). Clones D10 $0^{\Delta g d h}-1$ and D10 $0^{\Delta g d h}-2$ were used for further analyses.

Determination of total GDH activity in D10, D10 $0^{\Delta g d h}$ 1 and D10 $0^{\Delta g d h}-2$ showed that the majority of NADPH utilising activity is attributable to GDHa, as this activity is no longer detectable when the GDHa function is lost. The GDH activity of D10 was $36.9 \pm 0.35 \mathrm{nmol} / \mathrm{min} / \mathrm{mg}$ protein while the activity of $\mathrm{D} 10^{\Delta g d h}-1$ and $\mathrm{D} 10^{\Delta g d h}-2$ was less than $10 \mathrm{nmol} / \mathrm{min} / \mathrm{mg}$ protein, which was the detection limit of the assay system when $100 \mu \mathrm{g}$ protein was used. It was only possible to determine the specific activity of the forward reaction for $\mathrm{GDH}$, as the reverse reaction was also below the detection limit at these protein concentrations. The NADH-dependent reduction of $\alpha$-ketoglutarate also seemed affected in D10 ${ }^{\Delta g d h}-1$ and $\mathrm{D} 10^{\Delta g d h}-2(10.6 \pm 4.1 \mathrm{nmol} / \mathrm{min} / \mathrm{mg}$ protein and $10.7 \pm$ $4.1 \mathrm{nmol} / \mathrm{min} / \mathrm{mg}$ protein, respectively) compared to D10 parasites $(20.1 \pm 0.5 \mathrm{nmol} / \mathrm{min} / \mathrm{mg}$ protein $)$ suggesting that the $\mathrm{NADH}$-dependent $\mathrm{GDH}$ activity is still present in the mutant parasite lines, albeit at lower levels.

\section{Growth of $P$. falciparum D10 $0^{\Delta g d h a}$ and susceptibility to elevated oxidative stress}

The effect of low (1\%) and high oxygen tension (20\%) on the growth rate of D10 ${ }^{\Delta g d h}-1$ and D $10^{\Delta g d h}-2$ was assessed and compared to that of D10 parasites. The absence of GDHa had no effect on the growth of D $10^{\Delta g d h}-1$ and D $10^{\Delta g d h}-2$ under low oxygen or elevated oxygen tension (Figure 3 ). This is surprising because it was previously suggested that GDHa is important for the generation of $\mathrm{NADPH}$, which is required for the parasite's antioxidant defence [13,17]. To test this hypothesis further, it was assessed whether D $10^{\Delta g d h}-1$ and D $10^{\Delta g d h}-2$ showed an increased susceptibility towards exogenous or endogenous oxidative stress. However, the $\mathrm{IC}_{50}$ values for $\mathrm{N}$-methylphenazonium methosulphate and tert-butylhydroperoxide determined for D $10^{\Delta g d h}-1$ and $\mathrm{D} 10^{\Delta g d h}-2$ were similar to those of the D10 wild type parasites (Table 1 ). These data do not corroborate the hypothesis that GDHa is crucial for a functional antioxidant defence of the parasites. 


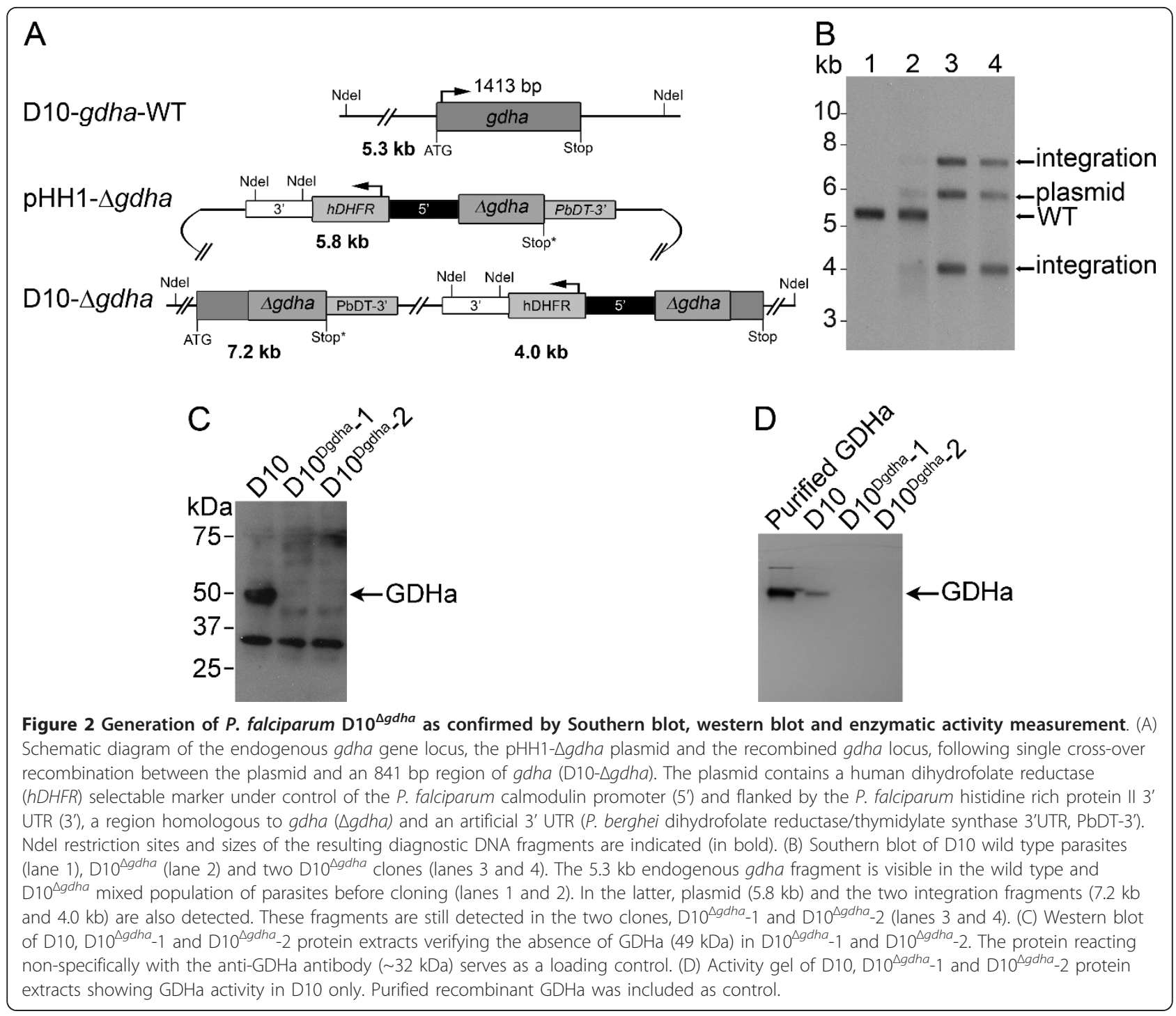

\section{Expression levels of proteins involved in antioxidant reactions}

In order to assess whether the absence of GDHa led to changes in the expression of proteins involved in antioxidant defences, of which some are NADPH-dependent, western blots of a variety of proteins were performed (Figure 4). The protein levels of the cytosolic 2Cys-peroxiredoxin and 1Cys-peroxiredoxin, the cytosolic and organellar superoxide dismutases 1 and 2, mitochondrial isocitrate dehydrogenase, glutathione reductase and cytosolic thioredoxin 1 did not change significantly in D10 $0^{\Delta g d h}-1$ and D $10^{\Delta g d h}-2$ compared to wild type D10. These results demonstrate that the parasites do not respond to the absence of GDHa by elevating the expression of their antioxidant protein repertoire, which suggests that they are not under enhanced oxidative stress. In addition, the transcript levels of $g d h b, g d h c$ and glucose-6-phosphate dehydrogenase, the major source of NADPH in the parasite cytoplasm, were analysed by quantitative real time PCR. Similar to the results described above, the mRNA levels of the three genes appeared to be similar in all parasite lines tested. The expression level of $g d h b$ is two-fold up-regulated (p $<0.05)$ in clone D10 $10^{\Delta g d h}-2$ but whether this change leads to an increase of GDHb protein remains to be investigated when antibodies against this protein are available (Table 2).

\section{Analyses of glutathione levels}

Apart from the parasite's enzymatic antioxidant repertoire it is possible that the loss of GDHa function may lead to changes in the level of the non-enzymatic antioxidant and redox buffer glutathione (GSH). The rationale for this suggestion is that the intracellular 


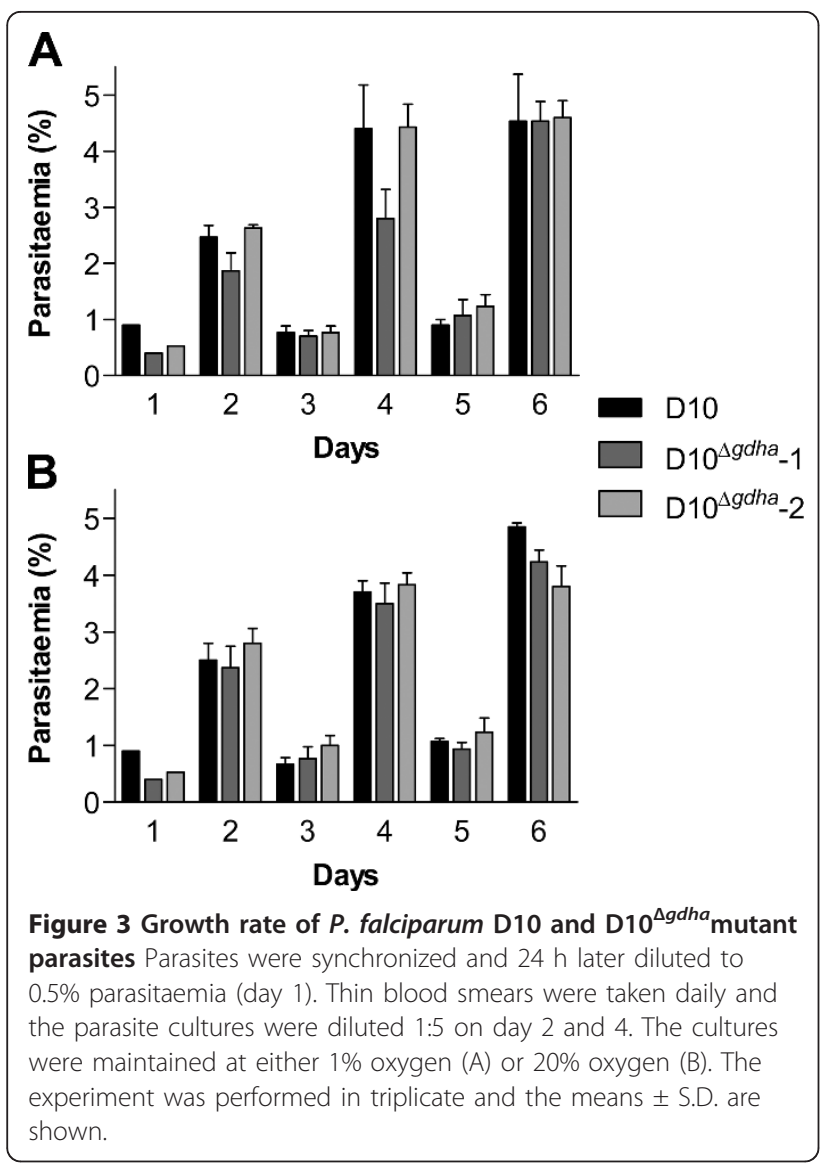

concentration of GSH is tightly regulated by NADPHdependent glutathione reductase and decreased levels of NADPH will affect the rate of glutathione disulphide (GSSG) reduction, potentially resulting in a lower amount of GSH and elevated levels of GSSG. The parasites are likely to respond to an increase in GSSG by excreting the tripeptide [43-45] which may result in a decrease in total GSH levels. However, the concentration of total GSH in D10 $0^{\Delta g d h}-1$ and D10 $0^{\Delta g d h}-2$, compared to D10, was not significantly changed $(831 \pm 59$ $\mathrm{nmol} / 10^{10}$ cells; $536 \pm 177 \mathrm{nmol} / 10^{10}$ cells and $677 \pm$ $117 \mathrm{nmol} / 10^{10}$ cells in D10, D10 ${ }^{\Delta g d h}-1$ and D $10^{\Delta g d h}-2$, respectively), suggesting that the reducing power in the parasite was not affected by the absence of GDHa.
Concurrently, the mRNA levels of the two genes involved in GSH biosynthesis, $\gamma$-glutamylcysteine synthetase ( $\gamma g c s)$ and glutathione synthetase ( $g s)$ were determined and it was found that $\gamma g c s$ mRNA levels were significantly increased between 2.1 and 2.8 fold in the D $10^{\Delta g d h}$ clones compared to D10 (Table 2), but this clearly does not lead to an increase in GSH.

\section{Metabolic labelling and metabolite analyses}

GDHa is thought to be of importance for the conversion of L-glutamate to $\alpha$-ketoglutarate and therefore instrumental to provide the carbon skeleton for the parasite's TCA pathway intermediates [46]. Synchronized D10, D $10^{\Delta g d h}-1$ and D $10^{\Delta g d h}-2$ and non-infected red blood cells were labelled with $\left[\mathrm{U}_{-}{ }^{13} \mathrm{C}\right]$ glutamine or $\left[\mathrm{U}_{-}{ }^{15} \mathrm{~N}, \mathrm{U}-\right.$ ${ }^{13} \mathrm{C}$ ] glutamine for 32 hours to identify potential changes in the metabolite composition of D $10^{\Delta g d h}-1$ and D10 $0^{\Delta g d h}-2$. Metabolites were extracted and incorporation of heavy isotopes was analysed by liquid chromatography followed by mass spectrometry as previously described [42,47].

The analyses showed that $\left[\mathrm{U}_{-}{ }^{13} \mathrm{C}\right]$ glutamine was converted into glutamate and subsequently into $\alpha$-ketoglutarate, which was then converted into succinate (Table 3). Small amounts of +3 and $+4\left[{ }^{13} \mathrm{C}\right]$ malate and +3 and $+4\left[{ }^{13} \mathrm{C}\right]$ fumarate were also detected in the parasites. These results are in agreement with those previously reported by Olszewski et al [42]. Surprisingly, the $\left[{ }^{13} \mathrm{C}\right]$ incorporation into $\alpha$-ketoglutarate and the other TCA pathway intermediates was similar in $\mathrm{D} 10^{\Delta g d h}-1$ and D $10^{\Delta g d h}-2$ compared to D10. These data strongly suggest that GDHa is either not, or not solely, responsible for the conversion of L-glutamate into $\alpha$ ketoglutarate in the parasites and thus is not essential for providing the carbon skeleton for TCA metabolism. This clearly indicates that this crucial reaction is catalysed by either one of the other two GDH proteins or alternatively by aminotransferases, which are responsible for the transfer of the amino group from glutamate and, depending on the acceptor, results in the production of aspartate, alanine or ornithine $[48,49]$. This was probed by assessing the effect of L-cycloserine, an inhibitor of aspartate and alanine aminotransferases [50,51].

Table $1 \mathrm{IC}_{50}$ values for oxidative stress inducers and an aminotransferase inhibitor for D10 and D10 ${ }^{\Delta g d h a}$ clones

\begin{tabular}{llll}
\hline & & \multicolumn{1}{c}{$\mathbf{I C}_{\mathbf{5 0}}$ values $(\boldsymbol{\mu M})$} \\
\hline Parasite line & N-methylphenazonium methosulfate & Tert-butylhydroperoxide & L-cycloserine \\
\hline D10 & $0.8 \pm 0.2$ & $76.7 \pm 20.0$ & $145.8 \pm 56.6$ \\
D10 & $0.7 \pm 0.2$ & $81.8 \pm 17.2$ & $113.5 \pm 37.5$ \\
D10 & $0.7 \pm 0.1$ & $81.3 \pm 15.5$ & $111.9 \pm 37.4$ \\
\hline
\end{tabular}

The effect on parasite viability by the endogenous stressor N-methylphenazonium methosulfate, the exogenous stressor tert-butylhydroperoxide and the aminotransferase inhibitor L-cycloserine were determined by the incorporation of $\left[{ }^{3} \mathrm{H}\right]$-hypoxanthine in the presence of increasing drug concentrations. The $\mathrm{IC}_{50}$ values were calculated by non linear regressing of the sigmoidal dose-response equation and shown are the mean \pm S.D. of two ( $N$-methylphenazonium methosulfate) or three (tert-butylhydroperoxide) independent experiments. For L-cycloserine the mean \pm S.E.M of six independent experiments is shown. 


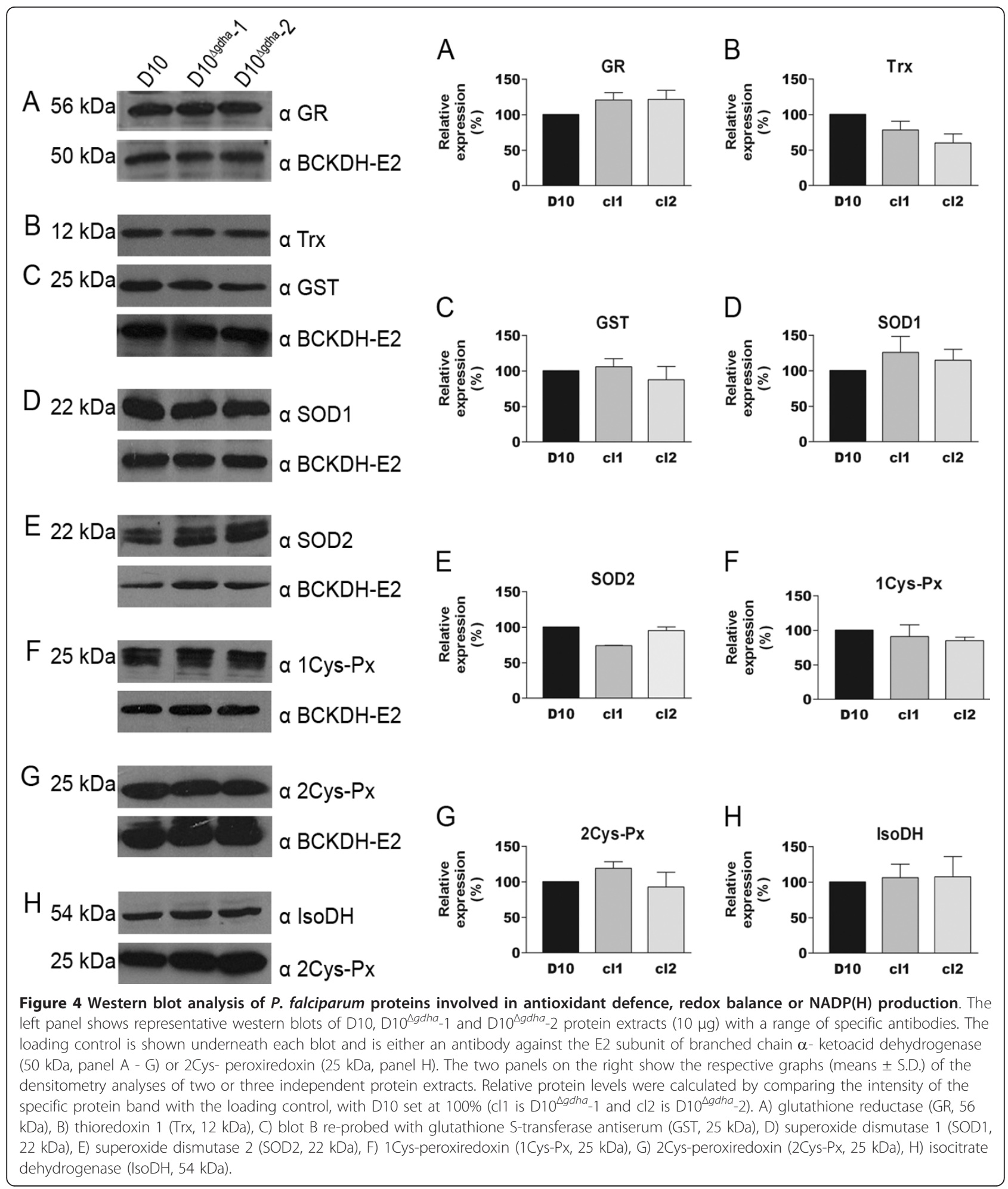

However, there was no difference in $\mathrm{IC}_{50}$ values between D10 wild type and the D $10^{\Delta g d h a}$ clones suggesting that these aminotransferases do not compensate for the loss of GDHa function (Table 1). The lack of any significant difference in incorporation of $\left[{ }^{15} \mathrm{~N}\right]$ into amino acids of wild type and mutant parasites after labelling with $\mathrm{U}$ $\left[{ }^{13} \mathrm{C}-{ }^{15} \mathrm{~N}\right]$-glutamine further supports this notion (data not shown). 
Table 2 Quantitative real time PCR of relevant genes from D10 and D10 ${ }^{\Delta \text { gdha }}$ clones

\begin{tabular}{llllll}
\hline Fold increase of mRNA compared to D10 \\
\hline Parasite line & $\boldsymbol{g}$ gpdh & gdhb & gdhc & gs & ggcs \\
\hline D10 $10^{\Delta d h a}-1$ & $1.8 \pm 0.7$ & $1.6 \pm 0.2$ & $1.4 \pm 0.3$ & $1.4 \pm 0.3$ & $2.1 \pm 0.2^{*}$ \\
D10 $10^{\Delta \text { gdha }-2}$ & $2.4 \pm 1.0$ & $2.2 \pm 0.3^{*}$ & $1.7 \pm 0.3$ & $1.5 \pm 0.4$ & $2.8 \pm 0.2^{*}$ \\
\hline
\end{tabular}

The amount of mRNA was calculated using seryl-t-RNA synthase as endogenous control and normalized to the amount of mRNA in D10. The values are the mean \pm S.D. of two independent experiments. ${ }^{*}$ denotes a significant difference in expression level compared to D10 $(p<0.05)$.

\section{Discussion}

The malaria parasite $P$. falciparum contains three genes encoding potential glutamate dehydrogenases; two are $\operatorname{NADP}(\mathrm{H})$-dependent proteins while the cofactor specificity of the third has not been determined to date [2,3]. A previous study, using cross-reacting antibodies, suggested that the parasites possess a cytosolic GDH protein without distinguishing which of the three GDH proteins is detected by the antibodies [52]. It was demonstrated here that GDHa-GFP, expressed episomally in P. falciparum, localizes exclusively to the parasite's cytosol while there is no GFP fluorescence present in the mitochondrion or the apicoplast. This is an unusual situation given that in mammals, plants and yeast, GDH are mitochondrial proteins $[1,5,53]$. However, the localization of GDH can change in senescence in plants, where the protein is distributed in organelle and cytosol [54].

The NAD $(\mathrm{H})$-dependent plant GDH and the mammalian $\mathrm{GDH}$ (using either $\mathrm{NAD}(\mathrm{H})$ or $\mathrm{NADP}(\mathrm{H})$ as co-factor) are responsible for the oxidative deamination of glutamate to provide $\alpha$-ketoglutarate as TCA cycle intermediate $[1,6,7,53]$. The $\operatorname{NADP}(\mathrm{H})$-dependent plant, yeast and bacterial enzymes catalyse the formation of glutamate by assimilating $\mathrm{NH}_{4}{ }^{+}$onto $\alpha$-ketoglutarate $[5,6]$. The Plasmodium GDHa is a NADP(H)-dependent protein and its kinetic parameters suggest that it can catalyse forward and reverse reactions. It has been argued that the $\mathrm{K}_{\mathrm{m}}$ value for $\mathrm{NH}_{4}{ }^{+}$, which is between 7

Table 3 Metabolic labelling resulting from growth of D10 and D10 $0^{\Delta \text { gdha }}$ clones with $\mathrm{U}-\left[{ }^{13} \mathrm{C}\right]$ glutamine-containing medium

\begin{tabular}{|c|c|c|c|}
\hline \multicolumn{4}{|c|}{ Percentage incorporation of $\left[{ }^{13} \mathrm{C}\right]$} \\
\hline $\begin{array}{l}\text { Parasite } \\
\text { line }\end{array}$ & $\begin{array}{l}+5-\left[{ }^{13} \mathrm{C}\right] \\
\text { glutamate }\end{array}$ & $\begin{array}{l}+5-\left[{ }^{13} \mathrm{C}\right] \alpha- \\
\text { ketoglutarate }\end{array}$ & $\begin{array}{l}+4-\left[{ }^{13} \mathrm{C}\right] \\
\text { succinate }\end{array}$ \\
\hline $\mathrm{rbc}$ & $60.5 \pm 1.1$ & 0 & $4.9 \pm 1.4$ \\
\hline D10 & $48.8 \pm 1.8$ & $47.1 \pm 3.4$ & $41.6 \pm 3.0$ \\
\hline $\mathrm{D}_{10} 0^{\Delta g d h a_{-1}}$ & $45.9 \pm 0.8$ & $49.7 \pm 4.1$ & $39.9 \pm 2.6$ \\
\hline $\mathrm{D} 10^{\Delta g d h a_{-2}}$ & $45.9 \pm 0.6$ & $53.0 \pm 3.3$ & $33.4 \pm 5.5$ \\
\hline
\end{tabular}

The parasite lines were cultured for $32 \mathrm{~h}$ with medium containing $2 \mathrm{mM} \mathrm{U}$ $\left[{ }^{13} \mathrm{C}\right]$ glutamine and metabolites extracted and analysed by LC-MS. The percentage of metabolite which has $\left[{ }^{13} \mathrm{C}\right]$ incorporated is shown. The values are the mean \pm S.D. of three independent experiments, which were done in triplicate. to $10 \mathrm{mM}$, is high suggesting that the enzyme is more likely to catalyse the formation of $\alpha$-ketoglutarate and the concomitant generation of NADPH [13]. Consequently it was proposed that the major role for GDHa in $P$. falciparum is to provide NADPH for vital antioxidant reactions and therefore it was deemed a potential target for antimalarial drug design $[3,13,14]$.

In this study, this hypothesis was tested by generating a $P$. falciparum line which no longer contains GDHa protein, by disrupting the gdha gene locus. The relative importance of GDHa for overall GDH activity was assessed by determining the enzyme activity in parasite extracts generated from D10 and D $10^{\Delta g d h a}-1$ and D10 ${ }^{\Delta g d h a}-2$. The NADPH-dependent reduction of $\alpha$ ketoglutarate in D10 was in good agreement with previously reported $\mathrm{GDH}$ activities $(36.9 \mathrm{nmol} / \mathrm{min} / \mathrm{mg}$ in D10 versus $63.0 \mathrm{nmol} / \mathrm{min} / \mathrm{mg}$, [18]). This NADPHdependent GDH activity was no longer detectable in the mutant parasite lines, suggesting that GDHa contributes the majority of this GDH activity during intra-erythrocytic parasite development and that the two other proteins, GDHb and GDHc, are only playing a minor role for the NADPH-dependent conversion of $\alpha$-ketoglutarate to glutamate. The oxidative deamination of glutamate was below detection limit in D10 wild type and mutant parasite lines, suggesting that GDHa is only marginally supportive of this reaction. This is supported by Vander Jagt et al [18]. Surprisingly, the loss of GDHa function had no negative effect on the growth of the mutant D10 $0^{\Delta g d h a}$ lines under normal culturing conditions. Similarly, applying oxidative stress by either increasing oxygen tension or exposing mutant parasites to pro-oxidants did not result in a growth defect or a change of $\mathrm{IC}_{50}$ values of tert-butylhydroperxoide and $\mathrm{N}$ methylphenazonium methosulfate. This may be attributable to increased levels of antioxidant proteins in $\mathrm{D} 10^{\Delta g d h a}$, which are up-regulated in response to the loss of GDHa function. However, enzymes that are part of the parasite's antioxidant repertoire did not show any alterations in their expression levels as assessed by western blotting. At mRNA level, no change was detected by real time PCR for the expression levels of $g d h c$, one of the other two genes potentially encoding $\mathrm{GDH}$, or $g$ 6-pdh, the enzyme likely to be responsible to provide NADPH for antioxidant reactions. The gene encoding GDHb was found to be up-regulated in clone D10 ${ }^{\Delta g d h a}$ 2 , while the other gene that showed a marginal up-regulation of expression in both $\mathrm{D} 10^{\Delta g d h a}$ clones was $\gamma g c s$, the rate limiting enzyme of GSH biosynthesis; however no concomitant increase in GSH levels in D10 ${ }^{\Delta g d h a}$ was detectable. Together these data suggest that GDHa has no obvious role in the defence against elevated levels of oxidative stress and that providing NADPH for redox reactions is unlikely to be its major role. 
The second reaction product of the oxidative deamination of glutamate by GDHa is $\alpha$-ketoglutarate, an intermediate of the $P$. falciparum TCA pathway $[42,46]$. However, the metabolic labelling experiments performed in this study show no difference in the incorporation of the carbon skeleton of $\left[{ }^{13} \mathrm{C}\right]$ labelled glutamine into $\alpha$ ketoglutarate, succinate and other TCA pathway intermediates between wild type and mutant parasites. This implies that either GDHa is not involved in the oxidative deamination of glutamate or that an alternative pathway compensates for the loss of GDHa function. The latter could be achieved by the two remaining GDH proteins although their mRNA expression levels appear only marginally changed upon gdha disruption. However, it is possible that their catalytic activities are elevated in the mutant parasites in response to metabolic changes occurring as a consequence of the absence of GDHa. The activity of GDH, from mammals to bacteria, is highly regulated by the availability of nitrogen and carbon sources [1] suggesting that this may also be possible in the malaria parasites. Clearly the parasites are able to remove toxic ammonia through an efficient aquaglyceroporin suggesting that considerable amounts of the metabolic end-product of amino acid metabolism can be dealt with to avoid intoxication [55].

Another possibility is that aminotransferases replace GDHa function $[48,49]$ but the susceptibility of $\mathrm{D} 10^{\Delta g d h a}$ parasites for the inhibitor L-cycloserine, acting against aspartate and alanine aminotransferases [50,51], was not altered compared to wild type parasites. Overall, these data provide evidence that GDHa is not important for the oxidative deamination of glutamate, but may have a role in generating glutamate through $\mathrm{NH}_{4}{ }^{+}$ assimilation.

Other organisms with multiple $g d h$ genes have a clear distinction between the catalytic activities of NADP $(\mathrm{H})$ and $\mathrm{NAD}(\mathrm{H})$-dependent enzymes. The $\mathrm{NAD}(\mathrm{H})$ - dependent proteins catalyse the generation of $\alpha$-ketoglutarate while the $\operatorname{NADP}(\mathrm{H})$-dependent GDH enzymes generate glutamate [4-6,8,11]. Glutamate metabolism is highly regulated and depends on the availability of carbon and nitrogen sources. In bacteria it was shown that GDH is only important for nitrogen assimilation when the concentration of $\mathrm{NH}_{4}{ }^{+}$is high and the bacteria are limited for energy (for instance in glucose-limited medium) $[56,57]$. Similarly, a NADP $(\mathrm{H})$-dependent GDH is involved in $\mathrm{NH}_{4}{ }^{+}$assimilation in fungi, but only under starvation conditions that limit the reactivity of the glutamine synthetase/glutamate synthase cycle [58,59]. The relatively high $\mathrm{K}_{\mathrm{m}}$ value for $\mathrm{NH}_{4}{ }^{+}$determined for the parasite GDHa suggests that it may function in a similar way to the bacterial and fungal GDH and synthesizes glutamate for nitrogen storage under starvation conditions, which is supported by the finding that the
NADPH-dependent conversion of $\alpha$-ketoglutarate into glutamate is indeed lost in the mutant D $10^{\Delta g d h a}$ lines. Under normal growth conditions in bacteria and fungi, glutamate is provided by glutamine synthetase and NADP $(\mathrm{H})$-dependent glutamine:2-oxoglutarate aminotransferase (glutamate synthase, GOGAT). Genes potentially encoding both of these proteins are present in the $P$. falciparum genome (PFI1110w: potential glutamine synthetase; PF14_0334: potential GOGAT). P. falciparum is cultured in vitro in the presence of $2 \mathrm{mM}$ glutamine and $11 \mathrm{mM}$ glucose supplying them with plenty of nitrogen and carbon sources. In fact, the supply of high concentrations of glutamine directly provides GOGAT with the substrate it needs to produce glutamate without the necessity to use glutamine synthetase, which depends on ATP hydrolysis. This artificial in vitro situation (high glutamine and glucose concentrations) favours the glutamate production via GOGAT so that the parasites do not rely on GDHa activity to synthesize glutamate, explaining the lack of any obvious phenotype of $\mathrm{D} 10^{\Delta g h d a}$ parasites.

This hypothesis raises important questions with respect to the metabolic functions of GDH in Plasmodium and needs further investigation. Clearly the roles of GDHb and GDHc need to be examined concomitantly to fully understand the significance of this interesting metabolic pathway in the parasites. However, these studies exclude a role of GDHa in antioxidant defence and we conclude that GDHa during erythrocytic development is not a suitable drug target given that the protein may only be important for parasite survival under limiting nutritional conditions.

\section{List of abbreviations}

GDHa: glutamate dehydrogenase a; GDHb: glutamate dehydrogenase b; GDHc: glutamate dehydrogenase c; GSH: glutathione; GSSG: glutathione disulphide; RBC: red blood cell; TCA: tricarboxylic acid.

\section{Acknowledgements}

The authors like to thank the Wellcome Trust for funding this work (WT061173MA-SM). Research leading to these results has received funding from the European Community's Seventh Framework Programme (FP7/20072013) under grant agreement $N^{\circ} 242095$. ML is funded by the Burroughs Wellcome Fund and an NIH Director's New Innovators award (1DP2OD001315-01) and receives support from the Center for Quantitative Biology (P50 GM071508). KO is funded by an NSF Graduate Research Fellowship. PCE was supported by a Fellowship grant from Science Foundation Ireland and IA received a postgraduate scholarship through the Centre for Synthesis and Chemical Biology funded through the Programme for Research in Third-Level Institutions of the Irish Higher Education Authority.

\section{Author details}

Institute of Infection, Immunity \& Inflammation, Wellcome Trust Centre for Molecular Parasitology, College of Medical, Veterinary and Life Sciences, Sir Graeme Davies Building, University of Glasgow, 120 University Place, Glasgow G12 8TA, UK. ' University College Dublin, School of Biomolecular and Biomedical Sciences, Conway Institute, University College Dublin, Belfield, Dublin, Republic of Ireland. ${ }^{3}$ Department of Molecular Biology, Lewis-Sigler Institute for Integrative Genomics, Princeton University, 
Princeton, NJ 08544, USA. ${ }^{4}$ Current address: Institute of Genetics, QMC, University of Nottingham, Nottingham NG7 2UH, UK.

\section{Authors' contributions}

JS carried out the molecular genetic studies, performed most of the phenotype analyses of gdha null mutant parasites including the metabolic labelling of parasites and analyses of metabolite datasets. In addition she made significant contributions to study design, data analyses and interpretation and also wrote part of the manuscript; JP carried out the western blot analyses and participated in other parts of the phenotype analyses of gdha null mutant parasites; IA cloned the knockout and GFP constructs and performed the in-gel GDHa assays; EMP determined the GSH level of wild type and mutant parasites; KO determined the metabolites after metabolic labelling and assisted in data analyses; ML contributed to data analyses and provided critical input into drafting the manuscript; PCE made substantive intellectual contributions to this study; SM made substantive intellectual contributions to study design, data analyses, interpretation and acquisition of data and wrote the manuscript. All authors have read and approved the final manuscript

\section{Competing interests}

The authors declare that they have no competing interests.

Received: 15 February 2011 Accepted: 14 July 2011

Published: 14 July 2011

\section{References}

1. Hudson RC, Daniel RM: L-glutamate dehydrogenases: distribution, properties and mechanism. Comp Biochem Physiol B 1993, 106:767-792.

2. Gardner MJ, Hall N, Fung E, White O, Berriman M, Hyman RW, Carlton JM, Pain A, Nelson KE, Bowman S, Paulsen IT, James K, Eisen JA, Rutherford K, Salzberg SL, Craig A, Kyes S, Chan MS, Nene V, Shallom SJ, Suh B, Peterson J, Angiuoli S, Pertea M, Allen J, Selengut J, Haft D, Mather MW Vaidya AB, Martin DM, Fairlamb AH, Fraunholz MJ, Roos DS, Ralph SA, McFadden Gl, Cummings LM, Subramanian GM, Mungall C, Venter JC, Carucci DJ, Hoffman SL, Newbold C, Davis RW, Fraser CM, Barrell B: Genome sequence of the human malaria parasite Plasmodium falciparum. Nature 2002, 419:498-511.

3. Aparicio IM, Marin-Menendez A, Bell A, Engel PC: Susceptibility of Plasmodium falciparum to glutamate dehydrogenase inhibitors-A possible new antimalarial target. Mol Biochem Parasitol 2010, 172:152-155.

4. Avendano A, Deluna A, Olivera H, Valenzuela L, Gonzalez A: GDH3 encodes a glutamate dehydrogenase isozyme, a previously unrecognized route for glutamate biosynthesis in Saccharomyces cerevisiae. J Bacteriol 1997, 179:5594-5597.

5. DeLuna A, Avendano A, Riego L, Gonzalez A: NADP-glutamate dehydrogenase isoenzymes of Saccharomyces cerevisiae. Purification, kinetic properties, and physiological roles. J Biol Chem 2001, 276:43775-43783.

6. Miyashita $Y$, Good AG: Glutamate deamination by glutamate dehydrogenase plays a central role in amino acid catabolism in plants. Plant Signal Behav 2008, 3:842-843.

7. Miyashita Y, Good AG: NAD(H)-dependent glutamate dehydrogenase is essential for the survival of Arabidopsis thaliana during dark-induced carbon starvation. J Exp Bot 2008, 59:667-680.

8. Abiko T, Wakayama M, Kawakami A, Obara M, Kisaka H, Miwa T, Aoki N, Ohsugi R: Changes in nitrogen assimilation, metabolism, and growth in transgenic rice plants expressing a fungal NADP(H)-dependent glutamate dehydrogenase (gdhA). Planta 2010, 232:299-311.

9. Robinson SA, Slade AP, Fox GG, Phillips R, Ratcliffe RG, Stewart GR: The role of glutamate dehydrogenase in plant nitrogen metabolism. Plant Physiol 1991, 95:509-516.

10. Labboun S, Terce-Laforgue T, Roscher A, Bedu M, Restivo FM, Velanis CN, Skopelitis DS, Moschou PN, Roubelakis-Angelakis KA, Suzuki A, Hirel B: Resolving the role of plant glutamate dehydrogenase. I. In vivo real time nuclear magnetic resonance spectroscopy experiments. Plant Cell Physiol 2009, 50:1761-1773.

11. Tang $Y$, Sieg A, Trotter PJ: (13)C-metabolic enrichment of glutamate in glutamate dehydrogenase mutants of Saccharomyces cerevisiae. Microbiol Res 2011.
12. Krauth-Siegel RL, Muller JG, Lottspeich F, Schirmer RH: Glutathione reductase and glutamate dehydrogenase of Plasmodium falciparum, the causative agent of tropical malaria. Eur J Biochem 1996, 235:345-350.

13. Wagner JT, Ludemann H, Farber PM, Lottspeich F, Krauth-Siegel RL: Glutamate dehydrogenase, the marker protein of Plasmodium falciparum-cloning, expression and characterization of the malarial enzyme. Eur J Biochem 1998, 258:813-819.

14. Werner C, Stubbs MT, Krauth-Siegel RL, Klebe G: The crystal structure of Plasmodium falciparum glutamate dehydrogenase, a putative target for novel antimalarial drugs. J Mol Bio 2005, 349:597-607.

15. Becker K, Tilley L, Vennerstrom $J$, Roberts D, Rogerson S, Ginsburg H: Oxidative stress in malaria parasite-infected erythrocytes: host-parasite interactions. Int J Parasitol 2004, 34:163-189.

16. Muller S: Redox and antioxidant systems of the malaria parasite Plasmodium falciparum. Mol Microbiol 2004, 53:1291-1305.

17. Muller S, Liebau E, Walter RD, Krauth-Siegel RL: Thiol-based redox metabolism of protozoan parasites. Trends Parasitol 2003, 19:320-328.

18. Vander Jagt DL, Hunsaker LA, Kibirige M, Campos NM: NADPH production by the malarial parasite Plasmodium falciparum. Blood 1989, 74:471-474.

19. Walter RD, Nordmeyer JP, Konigk E: NADP-specific glutamate dehydrogenase from Plasmodium chabaudi. Hoppe Seylers Z Physiol Chem 1974, 355:495-500.

20. Crowther GJ, Napuli AJ, Gilligan JH, Gagaring K, Borboa R, Francek C, Chen Z, Dagostino EF, Stockmyer JB, Wang Y, Rodenbough PP, Castaneda LJ, Leibly DJ, Bhandari J, Gelb MH, Brinker A, Engels IH, Taylor J, Chatterjee AK, Fantauzzi P, Glynne RJ, Van Voorhis WC, Kuhen KL: Identification of inhibitors for putative malaria drug targets among novel antimalarial compounds. Mol Biochem Parasitol 175:21-29.

21. Crabb BS: Transfection technology and the study of drug resistance in the malaria parasite Plasmodium falciparum. Drug Resist Updat 2002, 5:126-130.

22. Reed MB, Saliba KJ, Caruana SR, Kirk K, Cowman AF: Pgh1 modulates sensitivity and resistance to multiple antimalarials in Plasmodium falciparum. Nature 2000, 403:906-909.

23. Wrenger C, Muller S: Isocitrate dehydrogenase of Plasmodium falciparum. Eur J Biochem 2003, 270:1775-1783.

24. Gunther S, McMillan PJ, Wallace LJ, Muller S: Plasmodium falciparum possesses organelle-specific alpha-keto acid dehydrogenase complexes and lipoylation pathways. Biochem Soc Trans 2005, 33:977-980.

25. Gilberger TW, Schirmer RH, Walter RD, Muller S: Deletion of the parasitespecific insertions and mutation of the catalytic triad in glutathione reductase from chloroquine-sensitive Plasmodium falciparum 3D7. Mol Biochem Parasitol 2000, 107:169-179.

26. Krnajski Z, Gilberger TW, Walter RD, Muller S: The malaria parasite Plasmodium falciparum possesses a functional thioredoxin system. Mol Biochem Parasitol 2001, 112:219-228.

27. Krnajski Z, Walter RD, Muller S: Isolation and functional analysis of two thioredoxin peroxidases (peroxiredoxins) from Plasmodium falciparum. Mol Biochem Parasitol 2001, 113:303-308.

28. Akerman SE, Muller S: 2-Cys peroxiredoxin PfTrx-Px1 is involved in the antioxidant defence of Plasmodium falciparum. Mol Biochem Parasitol 2003, 130.75-81.

29. Trager W, Jensen JB: Human malaria parasites in continuous culture. Science 1976, 193:673-675.

30. Lambros C, Vanderberg JP: Synchronization of Plasmodium falciparum erythrocytic stages in culture. J Parasitol 1979, 65:418-420.

31. Umlas J, Fallon JN: New thick-film technique for malaria diagnosis. Use of saponin stromatolytic solution for lysis. Am J Trop Med Hyg 1971, 20:527-529.

32. Crabb BS, Cowman AF: Characterization of promoters and stable transfection by homologous and nonhomologous recombination in Plasmodium falciparum. Proc Natl Acad Sci USA 1996, 93:7289-7294.

33. Kirkman LA, Su XZ, Wellems TE: Plasmodium falciparum: isolation of large numbers of parasite clones from infected blood samples. Exp Parasitol 1996, 83:147-149.

34. Desjardins RE, Canfield CJ, Haynes JD, Chulay JD: Quantitative assessment of antimalarial activity in vitro by a semiautomated microdilution technique. Antimicrob Agents Chemother 1979, 16:710-718.

35. Gunther S, Wallace L, Patzewitz EM, McMillan PJ, Storm J, Wrenger C, Bissett R, Smith TK, Muller S: Apicoplast lipoic acid protein ligase B is not essential for Plasmodium falciparum. PLoS Pathog 2007, 3:e189. 
36. Smith JD, Kyes S, Craig AG, Fagan T, Hudson-Taylor D, Miller LH, Baruch DI, Newbold Cl: Analysis of adhesive domains from the A4VAR Plasmodium falciparum erythrocyte membrane protein-1 identifies a CD36 binding domain. Mol Biochem Parasitol 1998, 97:133-148

37. Bradford MM: A rapid and sensitive method for the quantitation of microgram quantities of protein utilizing the principle of protein-dye binding. Anal Biochem 1976, 72:248-254.

38. Mamoun CB, Goldberg DE: Plasmodium protein phosphatase $2 \mathrm{C}$ dephosphorylates translation elongation factor 1 beta and inhibits its PKC-mediated nucleotide exchange activity in vitro. Mol Microbiol 2001, 39:973-981.

39. Salanti A, Staalsoe T, Lavstsen T, Jensen AT, Sowa MP, Arnot DE, Hviid L, Theander TG: Selective upregulation of a single distinctly structured var gene in chondroitin sulphate A-adhering Plasmodium falciparum involved in pregnancy-associated malaria. Mol Microbiol 2003, 49:179-191.

40. Mosmann T: Rapid colorimetric assay for cellular growth and survival: application to proliferation and cytotoxicity assays. J Immunol Methods 1983, 65:55-63.

41. Williams RA, Westrop GD, Coombs GH: Two pathways for cysteine biosynthesis in Leishmania major. Biochem J 2009, 420:451-462.

42. Olszewski KL, Mather MW, Morrisey JM, Garcia BA, Vaidya AB, Rabinowitz JD, Llinas M: Branched tricarboxylic acid metabolism in Plasmodium falciparum. Nature 2010, 466:774-778.

43. Luersen K, Walter RD, Muller S: Plasmodium falciparum-infected red blood cells depend on a functional glutathione de novo synthesis attributable to an enhanced loss of glutathione. Biochem J 2000, 346(Pt 2):545-552.

44. Atamna $\mathrm{H}$, Ginsburg $\mathrm{H}$ : The malaria parasite supplies glutathione to its host cell-investigation of glutathione transport and metabolism in human erythrocytes infected with Plasmodium falciparum. Eur J Biochem 1997, 250:670-679.

45. Ayi K, Cappadoro M, Branca M, Turrini F, Arese P: Plasmodium falciparum glutathione metabolism and growth are independent of glutathione system of host erythrocyte. FEBS Lett 1998, 424:257-261.

46. Olszewski KL, Llinas M: Central carbon metabolism of Plasmodium parasites. Mol Biochem Parasitol 2011, 175:95-103.

47. Olszewski KL, Morrisey JM, Wilinski D, Burns JM, Vaidya AB, Rabinowitz JD, Llinas M: Host-parasite interactions revealed by Plasmodium falciparum metabolomics. Cell Host Microbe 2009, 5:191-199.

48. Berger LC, Wilson J, Wood P, Berger BJ: Methionine regeneration and aspartate aminotransferase in parasitic protozoa. J Bacteriol 2001, 183:4421-4434.

49. Wrenger C, Muller IB, Schifferdecker AJ, Jain R, Jordanova R, Groves MR: Specific inhibition of the aspartate aminotransferase of Plasmodium falciparum. J Mol Biol 405:956-971.

50. Lepore BW, Liu D, Peng Y, Fu M, Yasuda C, Manning JM, Silverman RB, Ringe D: Chiral discrimination among aminotransferases: inactivation by 4-amino-4,5-dihydrothiophenecarboxylic acid. Biochemistry 49:3138-3147.

51. Cornell NW, Zuurendonk PF, Kerich MJ, Straight CB: Selective inhibition of alanine aminotransferase and aspartate aminotransferase in rat hepatocytes. Biochem J 1984, 220:707-716.

52. Ling IT, Cooksley S, Bates PA, Hempelmann E, Wilson RJ: Antibodies to the glutamate dehydrogenase of Plasmodium falciparum. Parasitology 1986, 92(Pt 2):313-324.

53. Abiko T, Obara M, Ushioda A, Hayakawa T, Hodges M, Yamaya T: Localization of NAD-isocitrate dehydrogenase and glutamate dehydrogenase in rice roots: candidates for providing carbon skeletons to NADH-glutamate synthase. Plant Cell Physiol 2005, 46:1724-1734.

54. Kichey T, Le Gouis J, Sangwan B, Hirel B, Dubois F: Changes in the cellular and subcellular localization of glutamine synthetase and glutamate dehydrogenase during flag leaf senescence in wheat (Triticum aestivum L.). Plant Cell Physiol 2005, 46:964-974.

55. Zeuthen T, Wu B, Pavlovic-Djuranovic S, Holm LM, Uzcategui NL, Duszenko M, Kun JF, Schultz JE, Beitz E: Ammonia permeability of the aquaglyceroporins from Plasmodium falciparum, Toxoplasma gondii and Trypansoma brucei. Mol Microbiol 2006, 61:1598-1608.

56. Helling RB: Pathway choice in glutamate synthesis in Escherichia coli. J Bacteriol 1998, 180:4571-4575.

57. Helling RB: Why does Escherichia coli have two primary pathways for synthesis of glutamate? J Bacteriol 1994, 176:4664-4668.
58. Baars JJ, Op den Camp HJ, van der Drift C, Joordens JJ, Wijmenga SS, van Griensven $\sqcup$, Vogels GD: 15N-NMR study of ammonium assimilation in Agaricus bisporus. Biochim Biophys Acta 1996, 1310:74-80.

59. Perysinakis A, Kinghorn JR, Drainas C: Glutamine synthetase/glutamate synthase ammonium-assimilating pathway in Schizosaccharomyces pombe. Curr Microbiol 1995, 30:367-372.

doi:10.1186/1475-2875-10-193

Cite this article as: Storm et al:: Plasmodium falciparum glutamate dehydrogenase $a$ is dispensable and not a drug target during erythrocytic development. Malaria Journal 2011 10:193.

\section{Submit your next manuscript to BioMed Central and take full advantage of:}

- Convenient online submission

- Thorough peer review

- No space constraints or color figure charges

- Immediate publication on acceptance

- Inclusion in PubMed, CAS, Scopus and Google Scholar

- Research which is freely available for redistribution 